BOSQUE 25(2): 43-55, 2004

\title{
Effects of soil cultivation, fertilisation, initial seedling diameter and plant handling on the development of maturing Pinus radiata D. Don on Kaingaroa gravelly sand in the Central North Island of New Zealand
}

\author{
Efectos del cultivo del suelo, fertilización, diámetro inicial y manipulación de plantas \\ en el desarrollo de Pinus radiata D. Don cercano a la madurez en suelos arenosos \\ en Kaingaroa en el centro de la Isla Norte de Nueva Zelanda
}

\section{EUAN G. MASON}

New Zealand School of Forestry, University of Canterbury, Private Bag 4800, Christchurch 8020, Nueva Zelanda

\begin{abstract}
SUMMARY
Two experiments relating to establishment that had been established in 1978 and 1981 were re-measured at least twice following the initial growth period in order to examine the effects of soil cultivation, fertilisation, and seedling quality on maturing crops of radiata pine. Cultivation improved survival, and ripping the subsoil decreased the likelihood of windthrow. In addition, there was a modest divergence in growth due to ripping at one site. Rough tree handling during transplanting markedly reduced tree survival following planting, reduced initial growth, and increased stand variability. The consequence of the increase in stand variability was an early onset of mortality among roughly handled trees. A simulation with the 3-PG model assuming that ripping increased maximum available soil moisture showed an increase in basal area due to ripping of $2.5 \mathrm{~m}^{2} /$ ha by age 25 . The measured increase was $3.3 \mathrm{~m}^{2} / \mathrm{ha}$.
\end{abstract}

Key words: site preparation, physiological modeling, plant handling, seedling quality.

RESUMEN

Dos experimentos relacionados al establecimiento de plantaciones creadas en 1978 y 1981 fueron remedidos al menos dos veces siguiendo el período de crecimiento inicial, con el objetivo de examinar los efectos del cultivo del suelo, fertilización y calidad de plantas en el desarrollo de pino radiata cercano a la madurez. El cultivo del suelo mejoró la sobrevivencia y específicamente el subsolado disminuyó la probabilidad de caída de los árboles por viento. Adicionalmente, hubo una divergencia modesta en crecimiento, debido al subsolado en uno de los sitios. La manipulación indebida de plantas al momento de la plantación redujo marcadamente la sobrevivencia después de la plantación, redujo el crecimiento inicial y aumentó la variabilidad del rodal. La consecuencia del aumento en la variabilidad fue un inicio temprano de la mortalidad de los árboles manipulados indebidamente. Una simulación con el modelo 3-PG, asumiendo que el subsolado aumentó la máxima disponibilidad de humedad en el suelo, mostró un aumento en el área basal, debido al subsolado de $2,5 \mathrm{~m}^{2} / \mathrm{ha}$ a los 25 años. El incremento real medido fue de 3,3 $\mathrm{m}^{2} / \mathrm{ha}$.

Palabras clave: preparación del sitio, modelación fisiológica, manipulación de plantas, calidad de plantas. 
BOSQUE 25(2): 43-55, 2004

Effects of soil cultivation, fertilisation, initial seedling diameter and plant...

\section{INTRODUCTION}

Many experiments have shown that establishment practices such as soil cultivation, fertilisation, weed control, tree stock ground-line diameter and plant handling can affect plantation development during the first few years after planting (see (1), for an overall summary of plantation establishment practices in New Zealand). However, most experiments relating to establishment are abandoned after the first few years, and estimates of rotation-length effects of site preparation are rare. Moreover, there appear to be no evaluations of initial seedling diameter or tree handling practices beyond the first few years of a crop rotation. This paper describes effects of site preparation, fertilisation, and seedling characteristics in maturing radiata pine stands in two experiments in the Central North Island of New Zealand.

Snowdon and Waring (2) identified two alternative long-term responses of plantations to site preparation treatments. Response type I represented an initial gain in productivity that was not sustained throughout the rotation, while response type II was a sustained growth increase. Woollons et al. (3) examined growth responses of radiata pine to fertilisation in terms of yield at 10-18 years after planting, reporting yield increases in three experiments, and a yield decrease in one experiment. Mason (1) proposed that these responses should be defined in terms of time gain rather than yield gain, and that a set of testable assumptions should be met in order for a type I response to occur. Apparent type I responses have been reported after weed control (4), soil cultivation $(5,6)$, and fertilisation (3). Snowdon and Waring (2) reported type I responses after weed control, and type II responses after fertilisation. On three sites, Woollons et al. (3) recorded a type II response after fertilisation. Mason et al. (6) found apparent type II responses after mounding in the Central North Island of New Zealand, and found that relevant regional growth and yield models failed to predict the observed growth patterns. In addition, Mason \& Milne (7) found that radiata pine exhibited type I responses to weed control and a type II response to fertilisation on sites in Canterbury, New Zealand.

Nursery practices and tree handling during transportation and planting influence seedling quality. Initial seedling groundline diameter (8), and rough and prolonged seedling handling during transport to a planting site (9) have been shown to affect radiata pine growth and survival after planting. Mason (10) modelled these impacts during the first five years following planting in the Central North Island, and showed that their impacts were more pronounced on harsh sites. The study reported here may contain summaries of the first measurements of their impacts later in the rotation.

Measurement of long-term responses to seedling quality and site preparation on a variety of sites can lead to more general conclusions about effects of management practices (7), but this is no substitute for understanding the nature of a response and modelling the processes involved. Growth and yield models typically used for yield projection are inadequate for projecting long-term responses to site management practices $(6,7)$. Models of physiological and site processes, however, can lead to poor projections because of compounded errors in their complex mix of sub-models. Hybrid models such as 3-PG (4) may offer the level of complexity required. 3-PG was used in the study described here to test hypothesised reasons for the observed results.

Two experiments in Kaingaroa Forest were used for the study. One included effects of fertilisation and soil cultivation, while the other involved soil cultivation and seedling quality. Results relating to cultivation during the first five years after planting in the latter experiment were reported previously (12). Ripping improved tree survival by $10 \%$, increased the depth of root growth from $15 \mathrm{~cm}$ below the surface to the depth of ripping, and slightly increased height growth during the first five years. Ripping also improved crop uniformity.

The objectives of study are:

1. To examine the effects of initial seedling ground-line diameter on survival and growth of radiata pine subjected to a variety of site preparation practices.

2. To test the hypothesis that soil cultivation, fertilisation, quality of seedling handling and seedling ground-line diameter had no lasting effect on growth or survival of maturing radiata pine growing on Kaingaroa Gravelly Sand.

3. To determine, as a preliminary investigation, whether or not the 3-PG model could be used as an aid to understanding any observed effects of site preparation. 
BOSQUE 25(2): 43-55, 2004

\section{MATERIAL AND METHODS}

The soil in both experiments was Kaingaroa Gravelly Sand (13), which was the main flow from a volcanic eruption from the Horomatangi reef area of Lake Taupo 1870 years ago. This soil is partly welded, and 10 to $15 \mathrm{~cm}$ below the surface its resistance to penetration exceeds the $3 \mathrm{Mpa}$ limit for radiata pine root extension identified by Sands et al. (14) and confirmed on this soil type by Mason \& Cullen (12).

Both sites were flat and prone to autumn and spring frosts. In order to avoid tree deaths from frosts, the sites were kept weed free by herbicide sprays during each of the first two years after planting.

Compartment 436, experiment 1835/1: A very frost-prone corner of compartment 436, Kaingaroa Forest, at an elevation of $591 \mathrm{~m}$ was chosen for the study. It was a frost hollow, and only a few scattered individuals from the previous crop of Pinus ponderosa had survived through to harvest in the hollow. The Ponderosa pine was harvested in 1980, and residual debris was burnt during the summer of 1980/81.

An experiment was designed with two factors, cultivation and fertilisation, arranged in a randomised complete block, cross-over design. There were three complete blocks. Cultivation treatment plots were arranged in three, $40 \mathrm{~m}$ lines, with $3 \mathrm{~m}$ between lines. Treatments were as follows:

1. Control, no cultivation

2. Extra spade cultivation during planting

3. A mound produced by 6 inverted discs

4. Winged ripping to a depth of $70 \mathrm{~cm}$

5. Winged ripping with a mound produced by 4 inverted discs

6. Winged ripping with a mound produced by 6 inverted discs

7. Winged ripping with a mound produced by 4 inverted discs and compacted by an hourglassshaped roller

8. Winged ripping with a mound produced by 6 inverted discs and compacted by an hourglassshaped roller.

Trees were planted during September 1981 at $2 \mathrm{~m}$ spacing within lines. They had a genetic growth and form rating of 7 (15). Four weeks af- ter planting half of each cultivation plot was fertilised by placing $80 \mathrm{gm}$ of diammonium phosphate in a slit $10 \mathrm{~cm}$ from each tree.

During late winter of the $5^{\text {th }}$ year after planting four trees were selected as crop trees from the middle 10 trees of each 30-tree subplot and pruned to retain $3.5 \mathrm{~m}$ of canopy length. 3 out of 10 trees in each boundary row were also selected and pruned. Unpruned trees were then thinned to waste. During the following two years, these trees were further pruned to an average height of either $4 \mathrm{~m}$ or $6 \mathrm{~m}$ in one or two extra pruning lifts respectively. The number of pruning lifts applied to each tree was recorded.

The middle line of each subplot was used for measurement. The depth to a hardpan was measured on each side of every tree in uncultivated ground using a probe. Heights were measured at ages $0,1,2,3,4,5,6$ and 16. Ground-line diameters (at $5 \mathrm{~cm}$ above ground level) were measured at ages 0,1,2 and 3, and diameters at breast height $(1.4 \mathrm{~m})$ were measured at ages 4, 5, 6 and 16 . Prior to thinning at age 5 , each tree was assessed for its suitability as a crop tree, and reasons for rejection were noted.

Mean height, basal area/ha, and stems/ha estimates were computed for each plot at each time of measurement where appropriate (basal area/ha was computed for only those years when dbhob had been measured). Analysis of covariance of estimates prior to thinning were conducted using plot mean mean ground-line diameter as a covariate. Measurements obtained after thinning were subjected to analyses of variance. In addition, linear contrasts to test the overall effects of ripping, mounding, mound compaction and cultivation were employed.

Assessments of stem quality and suitability as crop trees were tested using the FREQ procedure in SAS (16).

To examine the long-term relationship between initial seedling diameter and growth, mean stem height and mean dbhob at age 16 were computed by ground-line diameter class at time of planting.

Compartment 558, experiment R1961: The layout of experiment R1961 was described previously (12), but it is briefly summarised here, and extra plots added to examine effects of poor tree handling are also described below. The elevation was $640 \mathrm{~m}$, and the site was flat. The previous crop had been Pinus ponderosa. 
BOSQUE 25(2): 43-55, 2004

Effects of soil cultivation, fertilisation, initial seedling diameter and plant...

The initial design was a single factor, randomised complete block with 16 blocks. Treatments comprised ripping and a control (no ripping). Plots were $40 \mathrm{~m}$ long, and either 4 lines wide (ripping) or 3 lines wide (control). Although the prescribed ripping depth was $60 \mathrm{~cm}$, assessments with a probe showed that the soil had been ripped to a depth of $39 \mathrm{~cm}$ on average. During August of 1978, trees with a growth and form rating of 7 (Vincent \& Dunstan 1989) were planted at a spacing of $2 \mathrm{~m}$ within rows. One of the middle rows in the ripped plots was planted in the centre of the ripped line, while trees in the other three lines were planted on a small mound created by the ripping next to each ripped line. During the first five years after planting, the central $20 \mathrm{~m}$ of the middle rows in each plot were used for growth measurement, while the ends of the rows were used for root studies reported by Mason \& Cullen (12). After the assessment at age 5, pruning and thinning to waste to a target of 300 stems/ha were overseen by the forest owner, and tree selection was not controlled with respect to the experimental layout. To avoid extremes in stocking, the plots were expanded to include the boundary rows for subsequent measurements.

Extending measurements into the boundary rows was undertaken after carefully considering the effects of this on the comparison of treatments. It was noted that effects of ripping were quite small, and shading of boundary trees by those in adjacent plots may have had only a small impact. This may have been offset by some access to deeper soil in adjacent rip lines by trees in the boundaries of the control treatments. In addition, not all control treatment boundaries were next to ripped plots. On balance, it was judged that including boundary rows was more likely to lead to a slight underestimation of the effect of ripping than an overestimation

When the author and his colleagues were laying out and then carefully planting the experiment, we noted that the area surrounding the experiment was being planted. Seedling handling techniques used in the surrounding area were the same as those later improved upon by Robin Trewin et al. $(9,17,18)$. Trees planted in the surrounding area had been transported in plastic bags, and stored for a considerable period under black polythene tents. Planters were stuffing as many trees as possible into planting bags bags so that they could minimise their return trips to the polythene tents. They were planting as rapidly as possible by creating a single slit with one stroke of a spade, pushing a seedling into the slit, and then firming soil with one sharp stamp of the heel of a boot. The author resolved to watch the relative performance of well- handled and planted trees grown within the experiment and those surrounding the experiment.

In 1983 , four $40 \times 12 \mathrm{~m}$ plots were established alongside the northern boundary of the experiment. Measurements in these plots were initially used for assessing the impacts of juvenile instability on stem form (19), and the potential for quantifying impacts of poor tree handling at mid-rotation was realised later. Poor handling had been seen to impact on tree survival and growth elsewhere (9) and had been quantified during the juvenile growth period (10), and so effects on juvenile tree survival and growth were expected. The plots represented a unique opportunity to assess impacts of tree handling practices late in the rotation. After thinning, the two ripped treatments in R1961 were combined into one larger plot, and so the experiment became an incomplete block design with three treatments:

1. Ripping and good tree handling (16 blocks).

2. No ripping and good tree handling (16 blocks).

3. Ripping and poor tree handling (4 blocks).

In the well-handled treatments heights were measured at ages 1, 2, 3, 5, 6, 21 and 25, groundline diameters were measured at ages $1,2,3$, and 5 , and dbhob was measured at ages 6, 21, and 25 . In the poorly-handled treatment heights and dbhob were measured at ages 5, 21 and 25. At age 25, pruned height and crown height were measured in all plots. Stem defects and any instability were noted at times of measurement. In addition, measurements of stem sinuosity resulting from juvenile instability were measured at age 5. Growth, survival, stability, and stem sinuosity measurements during the first five years have been reported previously $(12,19)$.

In late January 2003, 25 trees from the unripped plots and 25 in the ripped plots were randomly selected and felled within the original designed experiment. This was done by another researcher without consulting the author. Although diameters at breast height were collected from these trees, 
the question of how to deal with the fact that they had been felled a few months prior to the measurement at year 25 was carefully considered. It was decided that including the measurements in an unadjusted form would be the most conservative way to deal with the difficulty, because not including late summer growth in the measurements of these trees would reduce the likelihood of detecting a difference between well-handled and poorly-handled treatments. The effect would be tiny and neutral with respect to the effect of ripping. Heights for these trees were estimated by using Petterson height versus dbhob equations (20) fitted to the rest of the trees in the experiment by treatment.

Mean height, basal area/ha, and stems/ha estimates were computed for each plot where appropriate. Analyses of covariance were conducted using mean initial ground-line diameter as a covariate for all estimates from ages 1 to 5 within the designed experimental area. Data collected after the pruning and thinning treatment at age 5 were subjected to analyses of covariance using stocking at age 6 as a covariate. Changes in spacing due to mortality and growth in basal area during intervals after thinning were also subjected to analysis of covariance.

In order to distinguish between a type I and a type II response (2), basal area growth between ages 9 and 21 and between ages 21 and 25 were computed and subjected to analysis of covariance with stocking at age 6 as a covariate.

Relative frequencies of trees alive and dead at age 25 in each treatment were plotted against height classes at age 21 and, in the case of the poorly handled trees, against height classes at age 5 .

Means of dbhob and height at age 25 were computed by ground-line diameter classes and compared.

In all analyses the LSMEANS estimates from SAS (16) were used for treatment means.

Use of model 3-PG to examine possible reasons for some of the observed effects: Model 3-PG (11) was parametarised for radiata pine using the parameter estimates listed in appendix 1. Monthly summaries of weather between 1978 and 1991 were used to run the model. The closest meteorological station to the site that had any particular measurement was selected. Meteorological Stations used were Kaingaroa Forest (station 1819) for tempera- ture, frost, and rainfall, and Rotorua Aero 2 (stations 1768 and 1770) for radiation and pan evaporation. Data were available at Kaingaroa between 1978 and 1994. 3-PG will automatically recycle weather data if the projection period exceeds their range. Simulations were attempted using the 16 year sequence of weather and also a single set of long run climatic averages.

The fertility parameter was used to adjust 3-PG so that estimates of mean dbhob fitted those observed within the control treatment in experiment R1961.

The maximum available soil water parameter was adjusted to test whether or not effects of ripping on soil water availability may have been responsible for some of the observed growth differences between ripped and control treatments. Will (21) estimated that pumice soils in Kaingaroa could retain approximately $1 / 3$ of their depth in equivalent available water at field capacity. This estimate was used as a guide when setting the maximum available soil water in $3-P G$ at $50 \mathrm{~mm}$ in the control treatment and $120 \mathrm{~mm}$ in the ripped treatment.

\section{RESULTS}

Compartment 436, experiment R1835/1: Mean soil depth to a hardpan did not differ between treatments, and was $16 \mathrm{~cm}$. Mean ground-line diameter at age 0 was significant as a covariate for almost all treatments up to age 5 that represented growth.

Fertilisation with diammonium phosphate significantly improved growth $(\mathrm{P}<0.004)$ immediately after planting, but the effect was small and it was not detectable after age 4 (table 1).

Soil cultivation did not significantly improve growth during the first five years following planting (table 2). Cultivation did, however, improve survival $(\mathrm{P}<0.001) .1667$ stems/ha were planted, and 1495 stems/ha remained in the control treatment by age five, compared to an average of 1664 trees/ha in mechanically cultivated plots. 1609 trees/ha remained in plots subjected to extra spade cultivation during planting.

Linear contrasts showed that ripped plots suffered significantly less windthrow than plots that were not ripped $(\mathrm{P}<0.008)$. Ripped plots averaged 556 stems/ha by age 16, while hand culti- 
BOSQUE 25(2): 43-55, 2004

Effects of soil cultivation, fertilisation, initial seedling diameter and plant...

TABLE 1

Effects of fertilisation in compartment 436 during the first five years.

Efectos de la fertilización en el rodal 436 durante los primeros cinco años de desarrollo.

\begin{tabular}{|c|c|c|c|c|c|c|c|}
\hline & \multicolumn{6}{|c|}{ Age (years) } & \\
\hline & 0 & 1 & 2 & 3 & 4 & 5 & \\
\hline Fertilised & \multicolumn{6}{|c|}{ Height (m) } & $\mathrm{CV}$ ht age 5 \\
\hline Yes & 0.26 & $0.66 \mathrm{a}$ & $1.52 \mathrm{a}$ & $2.68 \mathrm{a}$ & $4.23 \mathrm{a}$ & $5.60 \mathrm{a}$ & 13 \\
\hline \multirow[t]{2}{*}{ No } & 0.25 & $0.57 \mathrm{~b}$ & $1.36 \mathrm{~b}$ & $2.42 \mathrm{~b}$ & $3.95 \mathrm{~b}$ & $5.42 \mathrm{a}$ & 13 \\
\hline & \multicolumn{4}{|c|}{ Ground-line diameter $(\mathrm{cm})$} & \multicolumn{2}{|c|}{ Dbhob $(\mathrm{cm})$} & $\begin{array}{c}\text { Basal area age } 4 \\
\left(\mathrm{~m}^{2} / \mathrm{ha}\right)\end{array}$ \\
\hline Yes & 0.6 & $1.8 \mathrm{a}$ & $4.8 \mathrm{a}$ & $7.9 \mathrm{a}$ & $6.3 \mathrm{a}$ & 9.2 & $5.27 \mathrm{a}$ \\
\hline \multirow[t]{2}{*}{ No } & 0.6 & $1.5 \mathrm{~b}$ & $4.1 \mathrm{~b}$ & $7.2 \mathrm{~b}$ & $5.7 \mathrm{~b}$ & 8.9 & $4.61 \mathrm{~b}$ \\
\hline & \multicolumn{6}{|c|}{ Stocking (stems/ha) } & $\begin{array}{c}\text { Basal area age } 5 \\
\left(\mathrm{~m}^{2} / \mathrm{ha}\right)\end{array}$ \\
\hline Yes & 1667 & 1638 & 1624 & 1617 & 1617 & 1617 & 11.05 \\
\hline No & 1667 & 1654 & 1654 & 1654 & 1654 & 1647 & 10.73 \\
\hline
\end{tabular}

TABLE 2

Effects of cultivation in compartment 436 .

Efectos del cultivo del sitio en el rodal 436.

\begin{tabular}{|c|c|c|c|c|c|c|c|c|}
\hline & \multicolumn{8}{|c|}{ Age (years) } \\
\hline & 0 & 1 & 2 & 3 & 4 & 5 & 6 & 16 \\
\hline Cultivation & \multicolumn{8}{|c|}{ Height $(\mathrm{m})$} \\
\hline Control & 0.28 & 0.57 & 1.32 & 2.51 & 4.01 & 5.31 & 7.00 & 20.8 \\
\hline 6 dics & 0.25 & 0.7 & 1.61 & 2.73 & 4.38 & 5.86 & 7.40 & 21.1 \\
\hline Hand cult & 0.26 & 0.6 & 1.47 & 2.61 & 4.19 & 5.74 & 7.21 & 21.1 \\
\hline Rip/4 discs & 0.26 & 0.58 & 1.34 & 2.39 & 3.88 & 5.18 & 6.79 & 20.9 \\
\hline Rip/4d/roll & 0.22 & 0.6 & 1.42 & 2.53 & 4.00 & 5.39 & 6.78 & 20.6 \\
\hline Rip/6 discs & 0.26 & 0.66 & 1.51 & 2.62 & 4.10 & 5.58 & 6.91 & 21.2 \\
\hline Rip/6d/roll & 0.24 & 0.62 & 1.42 & 2.47 & 4.02 & 5.39 & 6.71 & 20.9 \\
\hline \multirow[t]{2}{*}{ Ripping } & 0.25 & 0.6 & 1.41 & 2.54 & 4.15 & 5.65 & 6.90 & 21.5 \\
\hline & \multicolumn{4}{|c|}{ Ground-line diameter $(\mathrm{cm})$} & \multicolumn{4}{|c|}{ Basal area $\left(\mathrm{m}^{2} / \mathrm{ha}\right)$} \\
\hline Control & 0.7 & 1.5 & 4.2 & 7.4 & 4.29 & 9.86 & 7.01 & $37.4 \mathrm{a}$ \\
\hline 6 dics & 0.6 & 1.9 & 4.9 & 8.1 & 5.95 & 12.39 & 7.57 & $46.1 \mathrm{~b}$ \\
\hline Hand cult & 0.7 & 1.6 & 4.5 & 7.6 & 5.26 & 11.09 & 7.41 & $36.7 \mathrm{a}$ \\
\hline Rip/4 discs & 0.7 & 1.5 & 4.2 & 7.1 & 4.11 & 9.35 & 6.34 & $40.5 \mathrm{~b}$ \\
\hline Rip/4d/roll & 0.6 & 1.7 & 4.4 & 7.3 & 4.9 & 11.06 & 6.42 & $40.0 \mathrm{~b}$ \\
\hline Rip/6 discs & 0.6 & 1.7 & 4.6 & 7.9 & 5.21 & 11.37 & 6.57 & $40.4 \mathrm{~b}$ \\
\hline Rip/6d/roll & 0.7 & 1.7 & 4.6 & 7.7 & 4.8 & 11.22 & 7.70 & $48.1 \mathrm{~b}$ \\
\hline \multirow[t]{2}{*}{ Ripping } & 0.6 & 1.6 & 4.4 & 7.4 & 5.03 & 10.82 & 7.31 & $46.4 \mathrm{~b}$ \\
\hline & \multicolumn{8}{|c|}{ Stocking (stems/ha) } \\
\hline Control & 1667 & $1553 \mathrm{a}$ & $1524 \mathrm{a}$ & $1495 \mathrm{a}$ & $1495 \mathrm{a}$ & 1495 a & 556 & $463 \mathrm{a}$ \\
\hline 6 dics & 1667 & $1667 \mathrm{~b}$ & $1667 \mathrm{~b}$ & $1667 \mathrm{~b}$ & $1667 \mathrm{~b}$ & $1667 \mathrm{~b}$ & 556 & $487 \mathrm{a}$ \\
\hline Hand cult & 1667 & $1610 \mathrm{~b}$ & $1610 \mathrm{~b}$ & $1609 \mathrm{~b}$ & $1609 \mathrm{~b}$ & $1609 \mathrm{~b}$ & 556 & $510 \mathrm{a}$ \\
\hline Rip/4 discs & 1667 & $1657 \mathrm{~b}$ & $1653 \mathrm{~b}$ & $1649 \mathrm{~b}$ & $1649 \mathrm{~b}$ & $1649 \mathrm{~b}$ & 556 & $556 \mathrm{~b}$ \\
\hline Rip/4d/roll & 1667 & $1667 \mathrm{~b}$ & $1667 \mathrm{~b}$ & $1667 \mathrm{~b}$ & $1667 \mathrm{~b}$ & $1667 \mathrm{~b}$ & 556 & $556 \mathrm{~b}$ \\
\hline Rip/6 discs & 1667 & $1667 \mathrm{~b}$ & $1667 \mathrm{~b}$ & $1674 \mathrm{~b}$ & $1674 \mathrm{~b}$ & $1674 \mathrm{~b}$ & 556 & $556 \mathrm{~b}$ \\
\hline Rip/6d/roll & 1667 & $1660 \mathrm{~b}$ & $1653 \mathrm{~b}$ & $1649 \mathrm{~b}$ & $1649 \mathrm{~b}$ & $1649 \mathrm{~b}$ & 556 & $556 \mathrm{~b}$ \\
\hline Ripping & 1667 & $1667 \mathrm{~b}$ & $1648 \mathrm{~b}$ & $1651 \mathrm{~b}$ & $1651 \mathrm{~b}$ & $1650 \mathrm{~b}$ & 556 & $556 \mathrm{~b}$ \\
\hline
\end{tabular}


BOSQUE 25(2): 43-55, 2004

vated, mounded only and control plots had a mean stocking of 486 stems/ha. Windthrow was most prevalent in the year following thinning, but recent windthrow was recorded in the latter treatment plots when they were remeasured at age 16 . Windthrow consisted entirely of uprooted trees, and it was clear that their root systems had not extended below $16 \mathrm{~cm}$ from the soil surface.

Windthrow in the control and hand cultivated plots resulted in a significant reduction in basal area by age $16(\mathrm{P}<0.04)$, while unripped/mounded plots had similar basal area/ha to other cultivated treatments. Basal area/ha at age 16 was 43.6 and $37.0 \mathrm{~m}^{2} / \mathrm{ha}$ in the mechanically cultivated and control/hand cultivation treatments respectively.

The $\log$ of individual tree initial ground-line diameter was significantly correlated to diameter at breast height at age $5(\mathrm{P}<0.0098)$ but not at age 16 .

The proportion of trees at age 5 that were suitable for selection as crop trees was $53 \%$, and this did not differ significantly with treatment. The most common reasons for rejection were basket whorls (whorls with many closely spaced branches that are a point of weakness in the stem) (27\%), toppling-related deformity (11\%), and multileadering $(7 \%)$.
Compartment 558, experiment R1961: Mean ground-line diameter at age 0 was significant as a covariate for all variables representing growth during the first two years.

As reported previously (Mason \& Cullen 1986), ripping improved survival during the first 3 years ( $\mathrm{P}<0.0051)$ after planting (table 3$)$, and height growth during the first 5 years $(\mathrm{P}<0.0001)$. By age five, stocking in the ripped plots had dropped from 1667 to 1438 stems/ha., while in the control plots it dropped to 1292 stems/ha. Mean height in the ripped plots was $4.55 \mathrm{~m}$, while in the control plots it was $4.08 \mathrm{~m}$. Ripping slightly increased ground-line diameter up to age three $(\mathrm{P}<0.03)$.

Cultivation and handling both significantly affected mean height at age 5. Coefficient of variation was larger in the unripped plots $(\mathrm{P}<0.04)$ and possibly also those containing poorly handled trees, but the latter difference was not statistically significant. The incomplete block design with only 4/16 blocks containing poorly handled trees accounts for an unusual pattern of significant differences for coefficient of variation in table 3 .

Residual stems/ha after thinning was significant as a covariate in analyses of stocking and basal area (table 4). Ripping increased growth after thinning up to age 21 in height $(\mathrm{P}<0.0162)$

TABLE 3

Effects of ripping and handling treatments during the first five years in compartment 558 . Efectos del subsolado y tratamientos de manipulación de plantas durante los primeros cinco anos de desarrollo en el rodal 558.

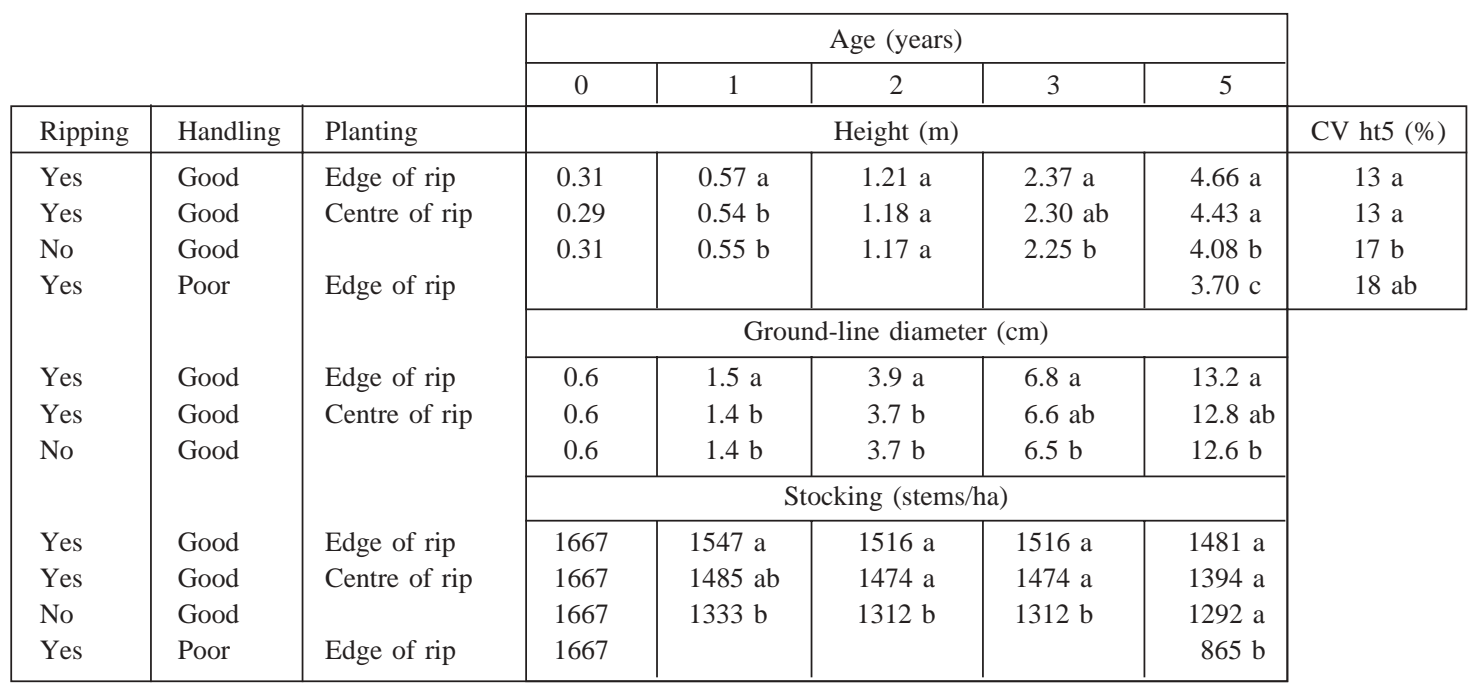


BOSQUE 25(2): 43-55, 2004

Effects of soil cultivation, fertilisation, initial seedling diameter and plant...

and basal area $(\mathrm{P}<0.0219)$. Following mortality in the last increment period, the difference in height was not statistically significant at age 25 . Only one tree was seen to be windthrown in the unripped treatment.

Poor handling of tree stocks reduced both height $(\mathrm{P}<0.0131)$ and basal area $(\mathrm{P}<0.0364)$ at age 21 . Excessive mortality in the poorly handled treatment meant that basal area was even further reduced $(\mathrm{P}<0.0061)$ at age 25 , but height was not significantly different. The mortality was found to be standing dead trees, not windthrow. Plotting mortality against height class in year 21 (figure 1) showed that suppressed trees were dying in the poorly handled treatment.

Basal area/ha growth slowly diverged between the ripped and unripped treatments up to age 21 . Divergence between these treatments was not statistically significant between ages 21 and 25 . Wellhandled stock grew significantly more in basal area/ ha between ages 21 and 25 than poorly-handled stock.
$81 \%$ of the trees in the poor handling treatment suffered from juvenile instability, compared to $37 \%$ in the well handled treatment. Likely consequences of this were examined in detail by Mason (19).

Individual tree ground-line diameter at age 0 was significantly correlated to ground-line diameter at age $5(\mathrm{P}<0.0032)$ but not at any age following thinning.

Use of model 3-PG to examine possible reasons for some of the observed effects: When used with the 16-year run of climatic data, increasing the maximum available soil water from $50 \mathrm{~mm}$ to $120 \mathrm{~mm}$ to simulate effects of ripping resulted in an increase of $2.5 \mathrm{~m}^{2} / \mathrm{ha}$ in basal area by age 25. Using long run annual averages in $3-P G$ showed an increase of $4.8 \mathrm{~m}^{2} / \mathrm{ha}$ in basal area per hectare after increasing maximum soil water. The measured value from compartment 558 was $3.3 \mathrm{~m}^{2} / \mathrm{ha}$.

TABLE 4

Effects of cultivation and tree handling in compartment 558 after thinning. Efectos del cultivo del sitio y manipulación de las plantas en el rodal 558 después del raleo.

\begin{tabular}{|c|c|c|c|c|c|c|}
\hline & & \multicolumn{5}{|c|}{ Age (years) } \\
\hline & & 6 & 7 & 9 & 21 & 25 \\
\hline Ripping & Handling & \multicolumn{5}{|c|}{ Height (m) } \\
\hline Yes & Good & 6.2 & 7.5 & $9.8 \mathrm{a}$ & $24.6 \mathrm{a}$ & 29.7 \\
\hline No & Good & 6 & 7.2 & $9.4 \mathrm{~b}$ & $23.8 \mathrm{~b}$ & 29.5 \\
\hline \multirow[t]{2}{*}{ Yes } & Poor & & & & $23.1 \mathrm{~b}$ & 29.4 \\
\hline & & \multicolumn{5}{|c|}{ Basal area $\left(\mathrm{m}^{2} / \mathrm{ha}\right)$} \\
\hline Yes & Good & 2.79 & 5.03 & 8.33 & $34.5 \mathrm{a}$ & $40.0 \mathrm{a}$ \\
\hline No & Good & 2.61 & 4.80 & 7.95 & $31.9 \mathrm{~b}$ & $36.7 \mathrm{~b}$ \\
\hline \multirow[t]{2}{*}{ Yes } & Poor & & & & $30.4 \mathrm{~b}$ & $32.8 \mathrm{~b}$ \\
\hline & & \multicolumn{5}{|c|}{ Stocking (stems/ha) } \\
\hline Yes & Good & $310^{*}$ & 291 & 291 & 295 & $293 \mathrm{a}$ \\
\hline No & Good & $274 *$ & 289 & 285 & 288 & $280 \mathrm{a}$ \\
\hline \multirow[t]{2}{*}{ Yes } & Poor & $318^{*}$ & & & 298 & $246 \mathrm{~b}$ \\
\hline & & \multicolumn{2}{|c|}{$\begin{array}{l}\text { Basal area growth, ages } \\
\quad 9-21\left(\mathrm{~m}^{2} / \mathrm{ha}\right)\end{array}$} & \multicolumn{2}{|c|}{$\begin{array}{c}\text { Basal area growth, ages } \\
21-25\left(\mathrm{~m}^{2} / \mathrm{ha}\right)\end{array}$} & \\
\hline Yes & Good & \multicolumn{2}{|c|}{$25.9 \mathrm{a}$} & \multicolumn{2}{|c|}{$5.52 \mathrm{a}$} & \\
\hline No & Good & \multicolumn{2}{|c|}{$23.7 \mathrm{~b}$} & \multicolumn{2}{|c|}{$4.76 \mathrm{a}$} & \\
\hline Yes & Poor & & & \multicolumn{2}{|c|}{$2.30 \mathrm{~b}$} & \\
\hline
\end{tabular}

* Unadjusted arithmetic means (plot values used as covariate). 
BOSQUE 25(2): 43-55, 2004 Effects of soil cultivation, fertilisation, initial seedling diameter and plant..
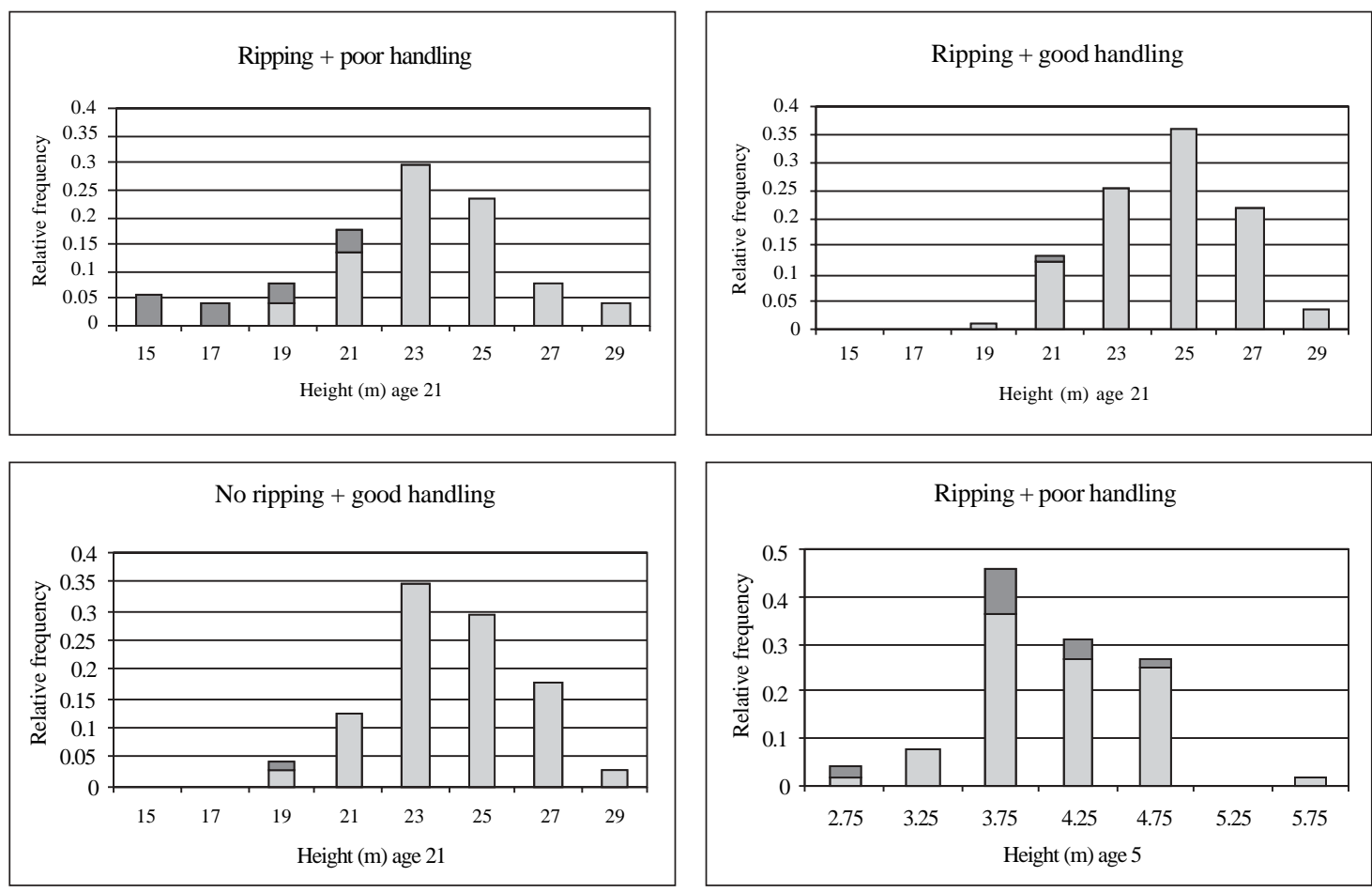

\section{Dead $\square$ Alive}

Figure 1. Height class distributions at age 21 and at age 5 vs living and dead trees at age 25 .

Distribución de alturas en dos etapas de desarrollo (a los 5 y 21 años de edad) en relación a los árboles vivos y muertos a los 25 años de edad.

\section{DISCUSSION}

Cultivation enhanced seedling survival in the years immediately following transplanting on both sites by approximately $10 \%$, which is what the initial growth model (10) predicts. The very large observed reduction in seedling survival resulting from poor tree handling is also predicted by the model. Mortality immediately after transplanting usually results from an inability of seedlings to establish good water supplies $(22,23)$. It is easy to understand how bruised, water-stressed trees with low starch reserves that result from poor handling $(18,24,25)$ would be less able to establish a water supply. The observed impact of cultivating soils that generally have a good ratio between air and water is less easily explained, however.

Ian Hunter ${ }^{1}$ once commented that even on sites where nutrients were not limiting to well

1 Pers. Communication, 2004. established trees, a small dose of fertiliser placed close to a seedling after planting might help it overcome a nutrient limitation imposed by poor soil contact of nursery-grown roots. This may explain the small, temporary increase in growth observed after fertilisation in compartment 436. It is likely that differences still existed at age 16, but they would have been small relative to variation between plots and therefore undetectable. This would constitute a type I response to fertilisation.

The response to tree handling late in the rotation was unexpected. It may be a consequence of greater variability in growth among poorly handled trees leading to more differentiation among canopy classes and hence earlier onset of mortality among suppressed trees. Variability in the first 5 years may not have been an issue, however. Trees in the well-handled, unripped treatment were initially more variable and yet they did not exhibit early mortality. The age 5 height 
BOSQUE 25(2): 43-55, 2004

Effects of soil cultivation, fertilisation, initial seedling diameter and plant...

class comparison in Figure 1 confirms that smaller trees at age 5 were not more prone to mortality after age 21 . Clearly some poorly-handled trees began to slow in growth later in the rotation and eventually died. The patterns in figure 1 provide compelling evidence that among well-handled tree stocks the canopy classes most prone to mortality after age 21 were not present. At a symposium in 1981, Wink Sutton ${ }^{1}$ mentioned that people felt that crop uniformity was of value, but they had not quantified it. The effects of variability on canopy dynamics and mortality observed during this study may contribute to the quantification of its worth. Mortality would almost certainly have increased after age 25 in the ripped and wellhandled treatment had the experiment been left to grow unmolested, and so this divergence may have been temporary.

A type II response to cultivation was observed in both experiments, but for differing reasons. In compartment 436 the divergence was due to windthrow on shallow, unripped soils, while the more modest divergence observed in compartment 558 was due to differing growth in ripped and unripped plots. Had the experiment in compart- ment 436 been monitored for longer, a divergent growth pattern may have been observed.

Simulations using model 3-PG suggest that soil water available during the life of the experiment in compartment 558 may account for the impact of ripping on productivity. This result demonstrated that a hybrid model like 3-PG can be very useful indeed for testing hypotheses about likely causes of observed effects of site preparation. Measurement of annual basal area growth in the stem discs extracted during January 2003 may provide an opportunity to test this assertion by examining the correlation between growth an available soil water predicted by 3-PG.

The author is currently involved in a collaborative project with Dr Landsberg, Dr Fredrik Nordborg (Swedish Agricultural University) and Dr Michael Perks (Northern Research Station, British Forestry Commission) to construct a 3-PG type hybrid for juvenile stands with discontinuous canopies. The question of how to include seedling quality in such a model has not yet been resolved, but results from the study reported here show that it is critical. Figure 2 presents a draft class diagram for effects of seedling quality.

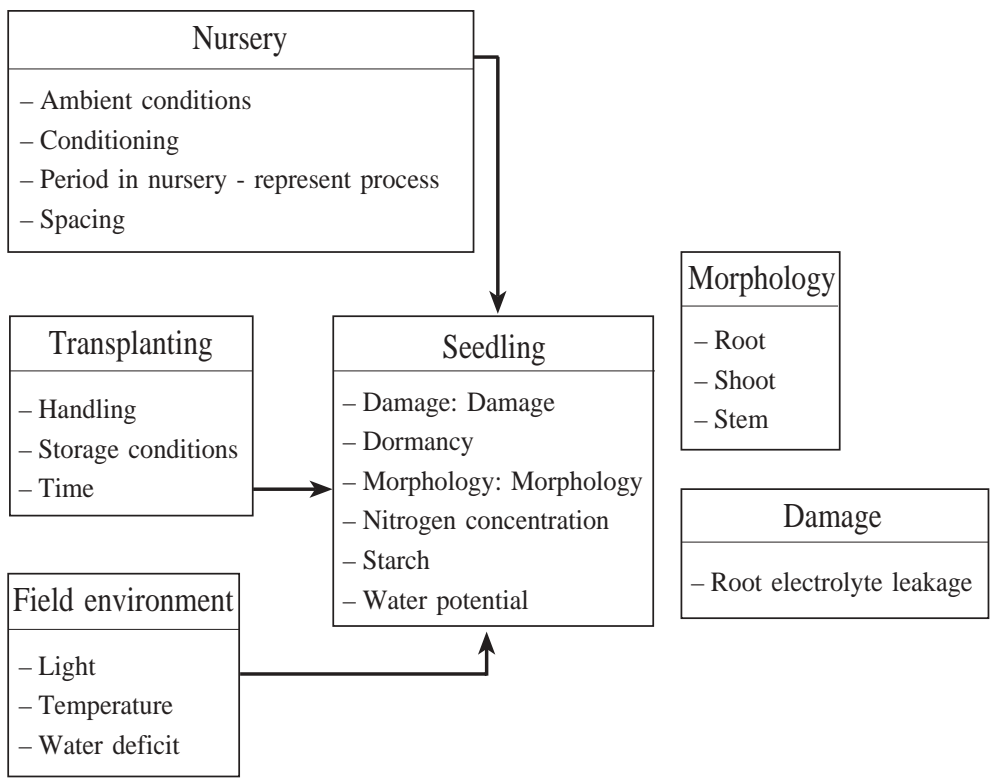

Figure 2. Class diagram representing possible structure for seedling quality in the physiological initial growth model project.

Diagrama de clases representando la posible estructura para la calidad de las plantas en el proyecto de modelación fisiológica del crecimiento inicial. 
BOSQUE 25(2): 43-55, 2004

Results from this study will add to a small number of reports of effects of establishment treatments in maturing stands, and should help forest managers with decisions about whether or not to spend money on stock quality, cultivation and fertilisation during plantation establishment.

\section{CONCLUSIONS}

Cultivation of Kaingaroa gravelly sand increased the survival of planted radiata pines by approximately $10 \%$, and this result was consistent across cultivation types and sites.

Cultivation modestly improved growth rates on one site, and markedly reduced the risk of windthrow on this shallow soil type. On both sites the effect of cultivation was a type II (divergent) response, but reasons for the response apparently differed. In one case it was a genuine growth response, while in the other it resulted from windthrow in the uncultivated treatments.

Rough handling of tree stocks during transplanting combined with poor planting reduced survival, increased juvenile instability, increased variability in the crop, reduced growth rates, and caused an early onset of mortality among suppressed trees late in the rotation.

\section{ACKNOWLEDGEMENTS}

The author wishes to thank many people who assisted with establishing and measuring the experiments, including John Cullen, Ian Page, Robin Trewin, Colin Saunders, Vic Wilton, Nigel Pink, Jacob Lazarus and Neil Woods. Provision of land by the New Zealand Forest Service, The NZ Forestry Corporation, Fletcher Challenge Forestry Ltd., and the Timber Management Company Ltd. is gratefully acknowledged. Thanks are due also to the Forest Research Institute, Rotorua, NZ, and the University of Canterbury, Christchurch, NZ for funding the study. Hannah Mason's efforts in entering data and Alan Leckie's knowledge of access to weather data were most helpful. Finally, thanks to Joe Landsberg for his advice and friendship.

\section{REFERENCES}

(1) MASON, E.G., Decision-support systems for establishing radiata pine plantations in the Central North Island of New Zealand. In: Forestry. 1992. Christchurch: University of Canterbury, p. 301.

(2) SNOWDON, P., H.D. WARING. Long-term nature of growth responses obtained to fertiliser and weed control applied at planting and their consequences for forest management. In: IUFRO symposium on site and site productivity of fast growing plantations. 1984. Pretoria and Petermaritzberg.

(3) WOOLLONS, R.C., A.G.D. WHYTE, D.J. MEAD. Long term growth responses in Pinus radiata fertiliser experiments. New Zealand Journal of Forestry Science, 1988, vol. $18, \mathrm{~N}^{\circ} 2$, p. 199-209.

(4) PREEST, D.S. Long-term growth response of Douglas fir to weed control. New Zealand Journal of Forestry Science, 1977, vol. 7, $\mathrm{N}^{\mathrm{o}} 3$, p. 329-332.

(5) WILHITE, L.P., E.P.J. JONES. Bedding effects in maturing slash pine stands. Southern Journal of Applied Forestry, 1981, vol. 5, No 1, p. 24-27.

(6) MASON, E.G., A.G.D. WHYTE, R.C. WOOLLONS, B. RICHARDSON. A model of the growth of juvenile radiata pine in the Central North Island of New Zealand: Links with older models, and rotation length analyses of the effects of site preparation. Forest Ecology and Management, 1997, vol. 97, p. 187-195.

(7) MASON, E.G., P.G. MILNE. Effects of weed control, fertilization, and soil cultivation on the growth of Pinus radiata at midrotation in Canterbury, New Zealand. In: Proceedings of the third International Conference on Forest Vegetation Management. 1998. Sault Ste. Marie, Ontario, Canada, August 24-28.

(8) MASON, E.G., D.B. SOUTH, W. ZHAO, W.Z. ZHAO. Performance of Pinus radiata in relation to seedling grade, weed control, and soil cultivation in the central North Island of New Zealand. 1995. In: Second International Conference on Forest Vegetation Management, 20-24.

(9) TREWIN, A.R.D., A.W.J. CULLEN. A fully integrated system for planting bare-root seedlings of radiata pine in New Zealand. In: IUFRO symposium on "Nursery management practices for the southern pines". 1985. Montgomery, Alabama, USA.

(10) MASON, E.G. A model of the Juvenile growth and survival of Pinus radiata D. Don: Adding The Effects of Initial Seedling Diameter and Plant Handling. New Forests, 2001, vol. 22, p. 133-158.

(11) LANDSBERG, J.J., R.H. WARING. A generalised model of forest productivity using simplified concepts of radiation-use efficiency, carbon balance and partitioning. Forest Ecology and Management, 1997, vol. 95, p. 209-228

(12) MASON, E.G., A.W.J. CULLEN. Growth of Pinus radiata on ripped and unripped Taupo pumice soil. New Zealand Journal of Forestry Science, 1986, vol. 16, № 1, p. 3-18.

(13) RIJKSE, W.C. Soils of the Kaingaroa Plateau, North Island, New Zealand. In: Soil Bureau District Office Report RO14. 1988, New Zealand Soil Bureau, DSIR.

(14) SANDS, R., E.L. GREACEN \& C.J. GERARD. Compaction of sandy soils in radiata pine forests. 1. A penetrometer study. Australian Journal of Soil Research, 1979, vol. 17, p. 101-113.

(15) VINCENT, T.G.D.J.S. Register of commercial seedlots issued by the New Zealand Forest Service. In: Bulletin. 1989, New Zealand Forest Research Institute. 155 p. 
BOSQUE 25(2): 43-55, 2004

Effects of soil cultivation, fertilisation, initial seedling diameter and plant...

(16) INSTITUTE, S. User's guide: Statistics - Version $5^{\text {th }}$ edition. 1985, Cary, North Carolina: SAS Institute.

(17) TREWIN, A.R.D., J.A.C. HUNTER. A containerised handling system for bare rooted seedlings. In: 18th IUFRO world congress. 1986. Ljubjana, Yugoslavia.

(18) TREWIN, A.R.D., J.C. VAN DORSSER. The integration of annual and mechanical operations involved in raising and planting bare-root seedlings of radiata pine in New Zealand. In: IUFRO symposium on "Equipment/silviculture interface in stand establishment operations”. 1985. Jasper, Alberta, Canada.

(19) MASON, E.G. Causes of juvenile instability of Pinus radiata in New Zealand. New Zealand Journal of For estry Science, 1985, vol. 15, No 3, p. 263-280.

(20) MCEWEN, A.D. N. Z. forest service computer system for permanent sample plots. In: New Zealand Forest Research Institute Symposium - 'Mensuration for Management Planning of Exotic Forest Plantations’. 1978. Rotorua, New Zealand.
(21) WILL, G.M., E.L. STONE. Pumice soils as a medium for tree growth. 1.Moisture storage capacity. New Zealand Journal of Forestry, 1967, vol. 12, № 2, p. 189-199.

(22) BURDETT, A.N. Physiological processes in plantation establishment and the development of specifications for forest planting stock. Canadian Journal of Forest Research, 1990, vol. 20, p. 415-427.

(23) VAN DORSSER, J.C. Seedling conditioning. In: New Zealand Forest Research Institute symposium 22 on "For est nursery and establishment practice in New Zealand". 1981. Rotorua, New Zealand: New Zealand Forest Research Institute.

(24) BALNEAVES, J., M.I. MENZIES. Lifting and handling procedures at Edendale Nursery - effects on survival and growth of 1/0 Pinus radiata seedlings. New Zealand Journal of Forestry Science, 1988, vol. 18, No 1, p. 132-134.

(25) MENZIES, M.I. Seedling quality and seedling specifications of radiata pine. In: What's New in Forest Research 1988, Forest Research Institute, Private bag, Rotorua, New Zealand, 4 p. 
BOSQUE 25(2): 43-55, 2004

Effects of soil cultivation, fertilisation, initial seedling diameter and plant..

\section{APPENDIX 1}

Parameters used in the 3-PG simulation.

Parámetros utilizados para la simulación 3-PG.

\begin{tabular}{|c|c|}
\hline Parameter & Value \\
\hline Allometric relationships \& partitioning & \\
\hline Foliage:stem partitioning ratio @ $\mathrm{D}=2 \mathrm{~cm}$ & 0.8 \\
\hline Foliage:stem partitioning ratio @ $\mathrm{D}=20 \mathrm{~cm}$ & 0.4 \\
\hline Constant in the stem mass v. diam. relationship & 0.0063 \\
\hline Power in the stem mass v. diam. relationship & 3.0436 \\
\hline Maximum fraction of NPP to roots & 0.8 \\
\hline Minimum fraction of NPP to roots & 0.15 \\
\hline Temperature modifier $(f T)$ & \\
\hline Minimum temperature for growth & 6 \\
\hline Optimum temperature for growth & 22 \\
\hline Maximum temperature for growth & 35 \\
\hline Frost modifier (fFRost) & \\
\hline Days production lost per frost day & 0.5 \\
\hline Soil water modifier (fSW) & \\
\hline Moisture ratio deficit for $\mathrm{f}_{\mathrm{q}}=0.5$ & 0.6 \\
\hline Power of moisture ratio deficit & 7 \\
\hline Fertitlity effects & \\
\hline Value of ' $\mathrm{m}$ ' when $\mathrm{FR}=0$ & 0 \\
\hline Value of 'fNutr' when FR $=0$ & 0.6 \\
\hline Age modifier (fAge) & \\
\hline Maximum stand age used in age modifier & 100 \\
\hline Power of relative age in function for fAge & 4 \\
\hline Relative age to give fAge $=0.5$ & 0.95 \\
\hline Litterfall \& root turnover & \\
\hline Maximum litterfall rate & 0.025 \\
\hline Litterfall rate at $\mathrm{t}=0$ & 0.001 \\
\hline Age at which litterfall rate has median value & 24 \\
\hline Average monthly root turnover rate & 0.015 \\
\hline Conductance & \\
\hline Maximum canopy conductance & 0.02 \\
\hline LAI for maximum canopy conductance & 3.33 \\
\hline Defines stomatal response to VPD & 0.05 \\
\hline Canopy boundary layer conductance & 0.2 \\
\hline
\end{tabular}

\begin{tabular}{|c|c|}
\hline Parameter & Value \\
\hline Stem numbers & \\
\hline Max. stem mass per tree @ 1000 trees/hectare & 300 \\
\hline Power in self-thinning rule & 1.5 \\
\hline $\begin{array}{l}\text { Fraction mean single-tree foliage biomass lost } \\
\text { per dead tree }\end{array}$ & 0 \\
\hline $\begin{array}{l}\text { Fraction mean single-tree root biomass lost } \\
\text { per dead tree }\end{array}$ & 0.3 \\
\hline $\begin{array}{l}\text { Fraction mean single-tree stem biomass lost } \\
\text { per dead tree }\end{array}$ & 0.2 \\
\hline Canopy structure and processes & \\
\hline Specific leaf area at age 0 & 8 \\
\hline Specific leaf area for mature leaves & 6 \\
\hline Age at which specific leaf area $=($ SLA0 + SLA 1$) / 2$ & 1 \\
\hline Extinction coefficient for absorption of PAR & \\
\hline by canopy & 0.5 \\
\hline Age at canopy cover & 8 \\
\hline Maximum proportion of rainfall evaporated & \\
\hline from canopy & 0.15 \\
\hline LAI for maximum rainfall interception & 4 \\
\hline Canopy quantum efficiency & 0.06 \\
\hline Branch and bark fraction (fracBB) & \\
\hline Branch and bark fraction at age 0 & 0.75 \\
\hline Branch and bark fraction for mature stands & 0.15 \\
\hline Age at which fracBB $=($ fracBB $0+$ fracBB 1$) / 2$ & 1.5 \\
\hline Various & \\
\hline Ratio NPP/GPP & 0.5 \\
\hline Basic density & 0.38 \\
\hline Conversion factors & \\
\hline Intercept of net $\mathrm{v}$. solar radiation relationship & -90 \\
\hline Slope of net v. solar radiation relationship & 0.8 \\
\hline Molecular weight of dry matter & 24 \\
\hline Conversion of solar radiation to PAR & 2.3 \\
\hline
\end{tabular}

